\title{
PERSEPSI MASYARAKAT TERHADAP KINERJA APARATUR DESA DALAM PENYELENGGARAAN PEMBANGUNAN DI DESA SUAK RIBEE KECAMATAN JOHAN PAHLAWAN KABUPATEN ACEH BARAT
}

\author{
Zulihar Mukmin, Ruslan, Siti Kurniati \\ Jurusan Pendidikan Pancasila dan Kewarganegaraan, Universitas Syiah Kuala \\ Jln. T. Nyak Arief Darussalam Banda Aceh \\ e-mail: ruslanaceh@yahoo.co.id
}

\begin{abstract}
This article discussed the public understanding of the duties and functions of the civilian apparatus in carrying out development, the public response to the performance of the civil apparatus in carrying out development, the performance of the apparatus when carried out their duties and functions to carry out development in accordance with the applicable rules. The method used a qualitative descriptive method. Data were collected through interviews with 15 respondents in Suak Ribee. The results of the study showed that in general, the community understood the duties and functions of the civil apparatus. The community acknowledges that the work capacity carried out by the authorities, especially public services, has met public expectations while the quality of work was recognized as good but not maximal due to lack of human resources
\end{abstract}

Keywords: public perception, performance of civil apparatus, development realization

\begin{abstract}
Abstrak: Kajian ini bertujuan untuk mempelajari pemahaman publik tentang tugas dan fungsi aparatur sipil dalam melaksanakan pembangunan, tanggapan publik terhadap kinerja aparatur sipil dalam melaksanakan pembangunan, kinerja aparatur ketika melaksanakan tugas dan fungsinya untuk melaksanakan pembangunan telah sesuai dengan prosedur yang berlaku. Kajian ini menggunakan metode deskriptif kualitatif. Data dikumpulkan melalui wawancara dengan 15 responden di Suak Ribee. Hasil Kajian menunjukkan bahwa pada umumnya masyarakat memahami tugas dan fungsi aparatur sipil. Masyarakat mengakui bahwa kapasitas kerja yang dilakukan oleh aparat, terutama layanan publik, telah memenuhi harapan publik sementara kualitas kerja diakui baik tetapi tidak maksimal karena kurangnya sumber daya manusia.
\end{abstract}

Kata Kunci: persepsi masyarakat, kinerja aparatur desa, penyelenggaraan pembangunan

Undang Undang Nomor 23 Tahun 2014 tentang Otonomi Daerah menitik beratkan pembangunannya pada daerah kabupaten/kota dengan memberikan kewenangan yang luas, nyata, dan bertanggungjawab. Keberhasilan otonomi daerah sangat ditentukan oleh kesiapan dan kemampuan daerah itu sendiri dalam mengelola dan memberdayakan seluruh potensi dan sumber daya yang tersedia dan bermuara pada terselenggaranya pemerintahan yang baik dan menghasilkan birokrasi handal, professional, efisien, produktif, serta memberikan pelayanan prima kepada masyarakat.

Otonomi daerah diupayakan dapat meningkatkan partisipasi masyarakatam pembangunan, sehingga pembangunan bersifat bottom up. Salah satu indikator keberhasilan otonomi daerah adalah meningkatnya pelayanan pemerintahan desa terhadap masyarakat dalam bentuk pelayanan publik. Oleh karena itu, pemerintah desa harus meningkatkan profesionalitasnya agar dapat memberikan pelayanan yangmaksimal kepada masyarakat, efektif, memiliki etos kerja, dan kompetitif.

Namun demikian, dalam realitasnya ditemukan fakta-fakta mengenai ketidak profe-sionalan aparatur desa dalam meningkatkan pembangunan dan cenderung memperioritaskan kedudukan dibandingkan pelaksanaan tugasnya. Selain itu, 
masih rendahnya kualitas kinerja dikarenakan tingkat pendidikan masih relatif rendah sehingga terbatasnya sumber daya manusia. Kurang penyediaaan dan pelatihan sarana dan prasarana teknologi informasi sehingga keterampilan aparatur desa kurang menguasai komputer serta kedisiplinan aparatur desa masih rendah.

\section{METODE}

Kajian ini menggunakan pendekatan kualitatif dengan jenis penelitian deskriptif dan dilakukan di Desa Suak Ribee Kecamatan Johan Pahlawan Kabupaten Aceh Barat. Dalam pemilihan subjek kajian menggunakan metode purposive sampling, dengan jumlah 15 orang yang mewakili dari masyarakat berdasarkan tingkat pendidikan terakhir Diploma, Strata 1, dan SMA. Tingkat pendidikan informan menjadi salah satu faktor yang mempengaruhi dan membentuk persepsi seseorang.

\section{HASIL DAN PEMBAHASAN}

Pemahaman Masyarakat Terhadap Tugas Pokok dan Fungsi Aparatur Desa dalam Penyelenggaraan Pembangunan

Berdasarkan hasil wawancara dengan masyarakat yang ada di Desa Suak Ribee Kecamatan Johan Pahlawan Kabupaten Aceh Barat bahwa semua informan mengetahui tentang tugas pokok dan fungsi (tupoksi) aparatur Desa Suak Ribee. Tolak ukur yang digunakan untuk mengatakan seorang memahami atau tidak mengenai tugas pokok dan fungsi aparatur desa (tupoksi) yaitu berdasarkan teori yang dikemukakan oleh Benjamin S.Bloom

(Sudijono, 2009:50) yang mengatakan: "Pemahaman (Comprehension) adalah kemampuan seseorang untuk mengerti atau memahami sesuatu itu diketahui dan diingat". Dengan kata lain memahami adalah mengerti tentang sesuatu dan dapat melihatnya dari berbagai segi.

Pengetahuan yang dimaksud dalam kajian ini adalah mengetahui tugas dan fungsi kepala desa untuk memimpin penyelengaraan pemerintah desa, membina kehidupan dan kerukunan gampong, menjaga dan memelihara kelestarian adat-istiadat yang berkembang dalam masyarakat, serta menjadi hakim adat dalam penyelesaian sengketa yang terjadi dalam masyarakat.
Sementara itu, tugas pokok dan fungsi sekretaris desa adalah membantu keuchik untuk kepentingan masyarakat, melayani masyarakat, membantu kepala desa dan mengurus urusan desa serta membantu keuchik dalam hal administrasi, bagian dari seorang pemimpin yang tugasnya bisa menjadi bawahan dari keuchik, salah satunya mencari data dan mengarsipkan data dari penduduk, melaksanakan tugas keuchik jika keuchik berhalangan keluar daerah, melaksanakan pengelolaan dalam surat menyurat, melaksanakan hal-hal yang mengenai dengan administrasi, membantu keuchik mencatat halhal mengenai sesuatu yang ada di gampong.

Hasil kajian menunjukkan bahwa masyarakat mengetahui tugas pokok dan fungsi kepala urusan, yaitu mengawasi pembangunan, membantu sekretaris desa, mengatur program yang diberikan oleh keuchik, mengkoordinasi pembangunan gampong, pembinaan kententraman dan ketertiban, mengurus data gampong perdusun, menyelesaikan masalah yang ada di gampong bersama imuem meunasah baik masalah sosial maupun masalah-masalah keadaan alam (banjir), menyelenggarakan pembangunan gampong, serta mengawasi hal-hal yang dibutuhkan di gampong.

Selanjutnya, masyarakat juga mengetahui tugas pokok dan fungsi kepala dusun adalah jika ada masalah penduduk diselesaikan terlebih dahulu oleh kepala dusun, membantu keuchik di wilayah kerjanya, melaksanakan kerja di tempat kepala dusun tinggal, mengawasi ketertiban penduduk di wilayahnya sendiri atau mengatur masyarakat di wilayah kerjanya memahami jumlah penduduk dan karakteristik dari warga di dusunnya, menjalankan kegiatan di daerahnya sendiri, menciptakan kegiatan-kegiatan yang kreatif untuk masyarakat di desa agar lebih produktivitas, menyelesaikan masalah yang timbul tepatnya di wilayah bertugas, serta mengkoordinasi dan memimpin warga di dusun.

Hasil kajian menunjukkan bahwa masyarakat mengetahui tugas pokok dan fungsi ketua pemuda adalah menjalankan perannya di bidang olahraga, mengadakan kegiatan kepemudaan, mengatur pemuda, membuat kegiatan- kegiatan gampong, mengurus remaja mesjid, melaksanakan kegiatan pemuda di gampong, organisasi dan remaja mesjid, meyelesaikan masalah tentang isu- isu yang ada di gampong, lebih menjurus kepada lingkungan yang lebih kecil atau masyarakat, melaksanakan kegiatankegiatan olah raga memimpin kegiatan kepemudaan, mengatur kegiatan gampong khususnya kegiatan 
pemuda, melaksanakan rencana pemuda gampong khususnya di bidang olahraga, dan apa yang dibutuhkan oleh pemuda, melakukan kegiatan pemuda, hal-hal bagian kepemudaan, serta menjaga keamanan jika ada pendatang.

Selanjutnya, masyarakat juga mengetahui tugas pokok dan fungsi ketua PKK adalah menjalankan acara-acara keterampilan ibu-ibu gampong, pelaksanaan koperasi gampong, mengurus semua kegiatan ibu-ibu misalnya pesta perkawinan, mengajak atau mengayomi ibu-ibu pengajian wirit yasin, membina ibu-ibu untuk melaksanakan kegiatan-kegiatan seperti wirit yasin, melakukan dan mensejahterakan kegiatan-kegiatan persatuan ibuibu gampong, mengelola kegiatan posyandu serta mengatur barang-barang PKK untuk kebutuhan kenduri masyarakat gampong setempat. Masyarakat juga mengetahui fungsi dan tugas pokok tuha peut adalah meningkatkan pelaksanaan syariat Islam, melaksanakan fungsi legilasi dan pengawasan, melakukan musyawarah atau duek pakat, melaksanakan dan menjaga kegiatan adat-sitiadat, menetapkan reusam gampong, bertanggungjawab dan melaksanakan berbagai kegiatan yang dilaksanakan di desa misalnya acara pernikahan masyarakat, berpartisipasi dalamkenduri gampong, menampung dan menyelurkan aspirasi masyarakat setempat kepada pemerintah gampong ketertiban atau menyelesaikan kejadian di gampong serta memberikan keputusan di saat rapat.

Selanjutnya, juga masyarakat mengetahui tugas pokok dan fungsi imeum meunasah adalah menjadi imam di mesjid, memimpin jika ada acara pernikahan, mengahadiri acara-acara orang yang telah meninggal dunia, mengayomi anak-anak mengaji, mengadakan majelis taklim, menghidupkan syiar baik itu tentang ibadah, harihari besar islam dan menghidupkan suasana yang Islami di gampong, serta melakukan hal-hal ibadah seperti mengumandangkan azan pada waktunya. Jadi, berdasarkan kajian yang telah dilakukan dapat dikatakan masyarakat mengetahui secara umumtugas pokok dan fungsi (tupoksi) aparatur Desa Suak Ribee Kecamatan Johan pahlawan Kabupaten Aceh Barat.

\section{Tanggapan Masyarakat Terhadap Kinerja Aparatur Desa dalam Penyelenggaraan Pembangunan}

Berdasarkan data di lapangan masyarakat menyatakan bahwa dari setiap pembangunan yang telah dilaksanakan untuk memenuhi dan melayani masyarakat di bidang infrastruktur maupun suprastruktur, aparatur Desa Suak Ribee telah melaksanakan berbagai program dalam membangun sarana dan prasarana infrastruktur desa yaitu jalan, saluran/drainase, sumur bor,wc umum, dan balai pengajian.

Di bidang suprastruktur aparatur Desa Suak Ribee telah memberikan pelayanan untuk kebutuhan masyarakat di bidang administrasi kependudukan seperti pengurusan surat-menyurat (KTP, KK, Akte Kelahiran, Akte Kematian, dan Surat Rekomendasi).Aparatur desa juga melaksanakan program penyaluran Beras Miskin (Raskin) dan bantuan usaha modal kecil, posyandu, penyaluran bantuan bebek dan lele yang diberikan kepada masyarakat bagi yang berhak menerima bantuan tersebut. Masyarakat juga memberikan tanggapan yang positif terhadap kinerja aparatur desa dalam penyelenggaraan pembangunan dan hanya beberapa informan saja memberikan tanggapan negatif berdasarkan yang diterima atau yang dirasakan oleh masyarakat setempat. Bagi aparatur desa kinerja yang dimaksud adalah hasil kepala desa beserta perangkatnya yang dicapai dalam suatu periode tertentu. Dengan demikian, kinerja kepala desa beserta perangkatnya ada beberapa indikator kerja guna mengetahui tingkat keberhasilan kerja. Adapun indikator yang dimaksud adalah kualitas, kuantitas, pelaksanaan tugas serta tanggung jawab terhadap suatu pekerjaan yang telah ditetapkan (Mangkunegara, 2009:67).

Selain itu, jika dilihat dari kuantitas kerja sudah memenuhi harapan masyarakat, ini dilihat dari kemampuan dalam melaksanakan tugasnya aparatur desa sangat mengutamakan kepentingan dan kebutuhan masyarakat serta dilihat dari motivasi kepala desa serta aparatur lainnya yang kuat untuk mencapai tujuan bersama. Kinerja aparatur Desa Suak Ribee dalam penyelenggaraan pembangunanan khususnya dalam hal pelayanan kepentingan surat menyurat (KK, KTP, Akte Kelahiran, dan Surat rekomendasi) sudah maksimal. Sebagaimana hal ini dikatakan oleh Nurcholis (2012:104) pelayanan pemerintah desa adalah sebuah pelayanan yang diterima oleh semua orang dalam memenuhi hak pelayanannya, seperti pemberian surat keterangan untuk pembuatan $\mathrm{KTP} / \mathrm{SIM} / \mathrm{SKCK} /$ sertifikat tanah, surat keterangan miskin, surat pengantar untuk pengobatan gratis. Selain itu kecepatan pelayanan 
yang diberikan kepada masyarakat aparatur Desa Suak Ribee telah memberikan pelayanan secara cepat atau tepat waktu, baik, tidak mengharapkan imbalan hanya saja masyarakat memberikan iuran seiklas hati sebagai tanda terimakasih, serta tidak mempersulit urusan, nyaman, bahkan aparatur desa melayani masyarakat di rumah. Prinsip pelayanan publik dalam Qanun Nomor 8 Tahun 2008 Pasal 16 meliputi: "sesuai dengan prosedur, kejelasan dan kepastian, nyaman, keterbukaan, kepastian dan tepat waktu, ekonomis, akurasi, tidak diskriminatif, bertanggung jawab, kejujuran, kelengkapan sarana dan prasarana, kemudahan akses, tidak menerima imbalan, kecermatan, kedisipilinan, akhlakul karimah, ketertiban".

Kedisiplinan aparatur desa dalam pelaksanaan tugas hanya sebagian aparatur Desa Suak Ribee saja yang sudah tepat waktu sesuai dengan aturan jam kerja yang telah ditetapkan bersama dan hanya ada beberapa aparatur desa yang belum memiliki kedisiplinan dalam menjalankan tugasnya dikarenakan lebih mementingkan urusan lain atau urusan pribadi pada jam kerja, dan kelalaian untuk menghabiskan waktu di luar. Dengan demikian, harapan masyarakat agar kedisplinan melaksanakan tugasnya ditingkatkan lagi agar lebih efektif.

Jika di lihat dari hasil kualitas kerja aparatur Desa Suak Ribee secara umum masyarakat menyatakan sudah baik, namun belum maksimal, misalnya dalam pembangunan lorong di dusun belum secara merata di perbaiki. Kemudian, pembangunan drainase yang belum optimal dibuat, sehingga tertahan air untuk mengalir. Hal ini disebabkan belum optimalnya upaya intensifikasi sumber-sumber pendapatan gampong yang sejalan dengan peraturan-peraturan perundang-undangan yang dapat menjamin penyelenggaraan pembangunan gampong dan sarana dan prasarana yang kurang memadai menyebabkan pelayanan publik yang kurang transparan, responsif, dan akuntabel belum dapat diwujudkan.

Ahmad dan Batinggi (2013:127-128) mengemukakan dimensi pengukuran kinerja sumber daya manusia, dengan menggunakan: "Kompetensi, yang dimaksud berupa pengetahuan, keterampilan, kemampuan, dan karakteristik kepribadian yang mempengaruhi kinerja secara langsung". Keterampilan dan ketelitian aparatur Desa Suak Ribee dalam melaksanakan pembangunan sama halnya dengan ketepatan kerja belum maksimal, sehingga pembangunan terhambat dikarenakan kurangnya Sumber Daya Manusia (SDM) yang masih relatif rendah serta kurangnya pelatihan pembinaan untuk aparatur Desa Suak Ribee, belum optimalnya penyediaan sarana dan prasarana teknologi informasi yang dapat meningkatkan kinerja dalam menyelengarakan pembangunan secara efesien dan efektif serta masih banyak aparatur desa kurang menguasai komputer. Sebagaimana dikemukakan Nawawi (2013:48) Kinerja pemerintahan harus memiliki hasil (oucomes), manfaat (benefit), dan dampak (impact) bagi masyarakat pengguna layanan. Itulah sebuah manajemen kinerja pemerintahan yang dapat dianggap baik atau berkualitas. Selanjutnya secara konseptual manjemen kinerja pemerintahan adalah suatu upaya untuk memperoleh dan meningkatkan hasil terbaik dari tujuan yang telah ditetapkan dalam suatu organisasi pemerintahan.

Aparatur Desa Suak Ribee dalam mengambil suatu keputusan melalui musyawarah atau sering disebut dengan duek pakat. Partisipasi masyarakat Desa Suak Ribee dalam proses pembangunan masih belum maksimal. Masyarakat ikut dilibatkan namun hanya saja tidak seluruh masyarakat, misalnya dijadikan pekerja dalam proyek pembangunan, memberikan ide-ide dan saran untuk pelaksanaan pembangunan, ikut menilai pembangunan yang telah di laksanakan, serta menjaga setiap sarana danprasarana yang sudah diberikan di Desa Suak Ribee.Masyarakat harus memberikan dukungan semangat berupa bentuk dan jenis partisipasi baik perencanaan, pelaksanaan, pemanfaatan dan pengawasan serta penilaian (Isbandi, 2007:27).

Aparatur Desa Suak Ribee belum sepenuhnya menerapkan prinsip-prinsip pemerintahan yang baik, misalnya kurangnya tingkat keadilan, profesionalitas, serta transparansi. Adapun prinsip-prinsip pemerintahan yang baik, yaitu: keikutsertaan, penegakkan hukum, keterbukaan, responsif, musyawarah, adil, efektivitas, tanggungjawab, dan visi strategis (Hidayat dan Azra, 2011: 161-165)".

Jadi, berdasarkan kajian yang telah dilakukan pandangan masyarakat terhadap kinerja aparatur desa dalam penyelenggaraan pembangunan dilihat dari segi kuantitas kerja sudah memenuhi harapan masyarakat. Dilihat dari segi kualitas kerja sudah baik namun belum maksimal. 


\section{Kinerja Aparatur Desa Sesuai dengan Prosedur Tugas Pokok dan Fungsinya (Tupoksi) dalam Penyelenggaraan Pembangunan}

Kinerja merupakan hasil yang dikerjakan dalam suatu organisasi yang dilaksanakan secara legal, tidak melanggar hukum, serta sesuai dengan tanggung jawab atas tugas yang diberikan. Dalam menjalankan tugas sebuah pemerintahan harus berdasarkan pada peraturan-peraturan yang berlaku. Sebagaimana dalamUndang-undang Nomor 6 Tahun 2014 pasal 26 ayat (1) menjelaskan bahwa:

"Kepala desa bertugas menyelengarakan pemerintahan desa, melaksanakan pembangunan desa, pembinaan masyarakat desa, dan pemberdayaan masyarakat desa".

Kemudian sebagaimana Qanun Nomor 5 Tahun 2003, Pasal 7 menyebutkan:

Pertama, perangkat gampong membantu keuchik dalam pelaksanaan fungsi, tugas, dan kewajibannya. Kedua, dalam pelaksanaan tugasnya sebagaimana dimaksud pada ayat (1) perangkat gampong langsung berada dibawah dan bertanggung jawab kepada keuchik. Ketiga, perangkat gampong diangkat dari penduduk gampong yang memenuhi syarat sesuai dengan kondisi sosial budaya masyarakat setempat. Keempat, perangkat gampong diangkat dan diberhentikan dengan keputusaan keuchik, setelah mendapatkan persetujuan dari tuha peut gampong.

\section{DAFTAR RUJUKAN}

Ahmad, Badu \& Batinggi.A. 2013. Manajemen Pelayanan Publik. Yogyakarta: Andi Offset.

Isbandi, Rukminto, Adi. 2007. Perencanaan Partisipatoris Berbasis Aset Komunitas: Dari Pemikiran Menuju Penerapan. Depok: FISIP UI Press.

Mangkunegara, A.P. 2009. Prilaku Organisasi Konsep dan Aplikasinya. Jakarta: PT Raja Grafindo Persada.

Moenir.2008. Manajemen Pelayanan Umum di Indonesia. Jakarta: PT. Bumi Aksara.
Hasil kajian menunjukkan bahwa kinerja keuchik telah sesuai dengan prosedur tugas pokok dan fungsinya. Sementara itu, sekretaris, kepala urusan kesejahteraan dan pembangunan, kepala dusun, ketua pemuda, ketua PKK, imuem meunasah dan tuha peut Desa Suak Ribee juga sudah sesuai dan hanya kepala urusan pemerintahan belum sesuai dengan tugas pokok dan fungsi di karenakan tidak sering masuk kerja, sehingga banyak tugas yang harus diselesaikan menjadi terhambat.

Sebagaimana menurut Moenir(2009:116) menjelaskan faktor kemampuan dengan sendirinya juga kata sifat/keadaan yang ditujukan pada sifat atau keadaan seseorang yang dapat melaksanakan tugas atau pekerjaan atas dasar ketentuan-ketentuan yang ada.

\section{SIMPULAN}

1. Pemahaman masyarakat terhadap tugas pokok dan fungsi aparatur desa dalam penyelenggaraan sudah baik pembangunan di Desa Suak Ribee Kecamatan Johan Pahlawan Kabupaten Aceh Barat.

2. Pandangan masyarakat di Desa Suak Ribee terhadap kinerja aparatur desa dalam penyelenggaraan pembangunan dari segi kualitas sudah memenuhi harapan masyarakat namun dari segi kuantitas belum maksimal.

3. Pandangan masyarakat tentang kinerja aparatur desa terhadap kesesuaian dengan tugas pokok dan fungsi (tupoksi) sudah sesuai dengan tugas pokok dan fungsi masing-masing.

Nawawi, Zaidan. 2013. Manajemen Pemerintahan. Jakarta: Rajawali Pers.

Nurcholis, Hanif. 2011. Pertumbuhan dan Penyelenggaraan Pemerintahan Desa. Jakarta: PT Grasindo.

Ndraha, Taliziduhu. 2011. Kybernology (Ilmu Pemerintahan Baru). Jakarta: Rineka Cipta.

Qanun No 5 tahun 2003 tentang Pemerintahan Gampong.

QanunProvinsiNanggroe Aceh Darussalam Nomor 8 Tahun 2008Tentang Pelayanan Publik 
Republik Indonesia, Undang-undangNomor 6 Tahun 2014 tentang Desa . (online), (http:/ /www.hukumonline.com, diakses 30 maret 2016).

Republik Indonesia, Undang-undang Nomor 23

Tahun 2014 Tentang Pemerintahan Daerah.
Sudijono, Anas. 2009. Pengantar Evaluasi Pendidikan. Jakarta: PT. RajaGrafindoPersada 